\title{
Antimicrobial activity and the presence of virulence factors and bacteriocin structural genes in Enterococcus faecium CM33 isolated from ewe colostrum
}

OPEN ACCESS

Edited by:

Jean-Christophe Augustin Ecole Nationale Vétérinaire d'Alfort,

France

Reviewed by:

Alexandra Lianou,

Agricultural University of Athens,

Greece

Eva-Guadalupe Lizárraga-Paulín, Instituto Tecnológico y de Estudios

Superiores de Monterrey, Mexico

*Correspondence:

Ahmad Yari Khosroushahi,

Drug Applied Research Center, and Department of Pharmacognosy,

Faculty of Pharmacy,

Tabriz University of Medical Sciences,

P.O. Box 51664-14766,

Daneshgah Street, Tabriz, Iran

yarikhosroushahia@tbzmed.ac.ir

Specialty section: This article was submitted to

Food Microbiology,

a section of the journal

Frontiers in Microbiology

Received: 27 May 2015

Accepted: 16 July 2015

Published: 29 July 2015

Citation:

Nami Y, Haghshenas $B$,

Haghshenas $M$ and

Yari Khosroushahi A (2015)

Antimicrobial activity

and the presence of virulence factors and bacteriocin structural genes in Enterococcus faecium CM33

isolated from ewe colostrum.

Front. Microbiol. 6:782. doi: 10.3389/fmicb.2015.00782

\author{
Yousef Nami' ${ }^{1}$ Babak Haghshenas ${ }^{1}$, Minoo Haghshenas ${ }^{2}$ and \\ Ahmad Yari Khosroushahi3,4*
}

${ }^{1}$ Institute of Biosciences, University Putra Malaysia, Selangor, Malaysia, ${ }^{2}$ School of Medicine, Shahid Beheshti University of Medical Sciences, Tehran, Iran, ${ }^{3}$ Drug Applied Research Center, Tabriz University of Medical Sciences, Tabriz, Iran,

${ }^{4}$ Department of Pharmacognosy, Faculty of Pharmacy, Tabriz University of Medical Sciences, Tabriz, Iran

Screening of lactic acid bacteria ( $L A B)$ isolated from ewe colostrum led to the identification and isolation of Enterococcus faecium CM33 with interesting features like high survival rates under acidic or bile salts condition, high tolerance for the simulated gastrointestinal condition, and high adhesive potential to Caco-2 cells. According the inhibition of pathogen adhesion test results, this strain can reduce more than 50\% adhesion capacity of Escherichia coli, Shigella flexneri, Klebsiella pneumoniae, Listeria monocytogenes, and Staphylococcus aureus to Caco-2 cells. Based on the antibiotic sensitivity test findings, E. faecium CM33 was susceptible to gentamycin, vancomycin, erythromycin, ampicillin, penicillin, tetracycline, and rifampicin, but resistant to chloramphenicol, clindamycin, and kanamycin. Upon assessment of the virulence determinants for $E$. faecium $\mathrm{CM} 33$, this strain was negative for all tested virulence genes. Furthermore, the genome of this strain was evaluated for the incidence of the known enterocin genes by specific PCR amplification and discovered the genes encoding enterocins $A, 31, X$, and $Q$. Based on this study findings, the strain E. faecium CM33 can be considered as a valuable nutraceutical and can be introduced as a new potential probiotic.

Keywords: antimicrobial activity, Enterococcus faecium, enterocins, probiotic, virulence genes

\section{Introduction}

The health promoting effects of probiotic bacteria are strain-specific, hence their discrimination and identification is very important and crucial under strain level by applying an efficient and valid strain-identification techniques such as $16 \mathrm{~S}$ rRNA sequencing. Besides, some identification methods can be utilized for assessment on the safety aspect and ecological properties of probiotics (Pereira and Gibson, 2002; Senok, 2009). The choice of appropriate probiotics is the most important base for enhancing the bio-therapeutic achievement in nutraceutical/pharmaceutical products. Several important characters of bacteria used as probiotics are the ability to survive in gastric conditions and adhere to the host intestinal cells (Kirjavainen et al., 1998; Dunne et al., 2001). However, in vitro procedures for choice of promising probiotics are necessary because in vivo methods are costly and need agreement by ethical committees. 
Caco-2 cells have been effectively applied to find the mechanism of cellular adhesion of non-pathogenic lactic acid bacteria (LAB; Tuomola and Salminen, 1998). It has also been explained that enterococci produce antimicrobial substances such as bacteriocins, hydrogen peroxide, and lactic acid (Sparo et al., 2006; Franz et al., 2007), which could elucidate their ability against several pathogens such as Staphylococcus aureus and Listeria monocytogenes. The connection of Enterococcus bacteria with human diseases has raised concern regarding their use as probiotic microorganisms (Franz et al., 2011). Several enterococcal strains are able to have antiviral activity (Wang et al., 2013), beneficial effects in anti-tumoral protective responses (Thirabunyanon and Hongwittayakorn, 2013) and can restore the microbiota balance in antibiotic-induced dysbiosis (Tarasova et al., 2010). Enterococcus bacteria, utilized in fermentation of vegetable products, meat, and dairy, are the reason of clinical infections. Therefore, it is vital to evaluate the virulence genes as well the antibiotic resistance profile.

Although the safety aspect of this genus is still blurred, members of enterococci are now engaged as probiotic bacteria to improve the immunity and human health (Brandão et al., 2010). The capability of these bacteria to make enterocins is remarkable and can be applied as food bio-preservatives (Khan et al., 2010). Bacteriocins are small, ribosomally synthesized and heat-stable peptides that apply antimicrobial activity against pathogenic bacteria or food spoilage, including Staphylococcus aureus, Clostridium spp. Bacillus spp., L. monocytogenes, and Campylobacter spp. (Nes et al., 2007; Line et al., 2008). Franz et al. (2007) categorized bacteriocins produced by Enterococcus bacteria into four different classes: Class I is lantibiotic enterocins such as cytolysin (CylLL/S; Gilmore et al., 1994); Class II is small, non-lantibiotic enterocins; Class III is cyclic enterocins for instance enterocin AS-48 (Eijsink et al., 2002); and Class IV is large proteins like enterolysin A (Hickey et al., 2003). There are three subclasses within class II including subclass IIa such as enterocin $\mathrm{A}$ and $\mathrm{P}$ (Ent $\mathrm{A}$ and Ent $\mathrm{P}$ ), which are pediocin-like bacteriocins; subclass IIb like enterocin L50 and Q (Ent L50A/B and Ent Q), which required two peptides for full antimicrobial activity and subclass IIc like enterocin B (Ent B), which are other linear and non-pediocin-type enterocins (Casaus et al., 1997).

Although there are rising concern about the safety of Enterococcus bacteria because of their relationship with several human infections (Brandão et al., 2010), a lot of works specify that enterococci play a key function in the improvement of the sensory properties of fermented foods like olives, sausages and cheese (Moreno et al., 2006). Carlos et al. (2010) elucidated a lot of virulence factors and their actions in Enterococcus bacteria (Carlos et al., 2010). These include the cylA which is in charge of the transportation and activation of the cytolisin; $c y l B$ and $c y l M$ involved in the post-translational modification; esp gene in charge of a cell wall protein involved in immune evasion; agg encodes an aggregation protein which is responsible for adherence to eukaryotic cells; gelE is in charge of toxin production that hydrolyzes gelatine and other compounds, and finally $c p d, c c f$, and cad genes encode sex pheromones, which are in charge of facilitating conjugation.
Because of the high potential of Enterococcus bacteria in health and food, the purpose of current study was to find out the antimicrobial activity and the presence of bacteriocin structural genes and virulence factors in Enterococcus faecium CM33 isolated from ewe colostrum to assess the potential probiotic properties and safety aspect of use of this strain.

\section{Materials and Methods}

\section{Bacteria Isolation}

Enterococcus faecium CM33 was isolated from ewe colostrum by culturing in de Man Rogosa and Sharpe broth (MRS) and following incubation of $50 \mu \mathrm{l}$ of cultured medium onto MRS agar supplemented with $6.5 \%(\mathrm{w} / \mathrm{v}) \mathrm{NaCl}(\mathrm{MRS}-\mathrm{NaCl})$ for $18 \mathrm{~h}$ at $37^{\circ} \mathrm{C}$ in aerobic conditions. After enrichment, five passages by isolated colony, the pure bacterium isolate was obtained.

\section{PCR Amplification of Isolate}

The amplification of $16 \mathrm{~S}$ rRNA gene $(1500 \mathrm{bp})$ of the isolate was performed by the primers (F $5^{\prime}$-AGAGTTTGATC CTGGCTCAG-3' and R 5'-GGCTGCTGGCACGTAGTTAG$\left.3^{\prime}\right)$, which those primarily used by Kullen et al. (2000). The amplification reaction was performed in a thermocycler (Thermo Electron Corporation, Waltham, MA, USA) with the following thermocycle program: Four min at $96^{\circ} \mathrm{C}$ as an initial denaturation; $30 \mathrm{~s}$ at $96^{\circ} \mathrm{C}$ as a denaturation for 30 cycles; $30 \mathrm{~s}$ at $48^{\circ} \mathrm{C}$ as an annealing and $45 \mathrm{~s}$ at $72 \mathrm{C}$ as an extension, with a final extension step for $4 \mathrm{~min}$ at $72^{\circ} \mathrm{C}$. The total volume of reaction was $50 \mu \mathrm{l}$. The PCR product was visualized through $0.8 \%(\mathrm{w} / \mathrm{v})$ agarose gel (Sigma Chemical Co., Poole, UK) electrophoresis by using ethidium bromide staining (Kullen et al., 2000). PCR product was sequenced by the Macrogen DNA Sequencing Service (Korea). The sequence was interrogated through the BLAST search of the NCBI database. The isolate was identified on account of the highest matching score.

\section{Effects of Heat, pH, and Hydrolytic Enzymes}

This strain was cultured in MRS broth for $18 \mathrm{~h}$ at $37^{\circ} \mathrm{C}$. After $10 \mathrm{~min}$ centrifugation at $12000 \mathrm{~g}$, cells were removed and the cell free supernatant (metabolites) was utilized for additional characterization. To determine the effect of $\mathrm{pH}$ on the metabolites action, $\mathrm{pH}$ of the crude supernatant was adjusted in the range between 1.5 and 9 by adding sterile $1 \mathrm{M} \mathrm{HCl}$ or $1 \mathrm{M} \mathrm{NaOH}$. Sample was incubated at room temperature for $4 \mathrm{~h}$. Thermostability of metabolites was determined at diverse temperatures. Crude supernatant was autoclaved at $121^{\circ} \mathrm{C}$ for $15 \mathrm{~min}$ and then incubated at different temperatures $(4,-20$, and $-70 \mathrm{C}$ ) for $24 \mathrm{~h}, 48 \mathrm{~h}, 2$ weeks, and 1 month.

The sensitivity of cell free supernatant toward different proteolytic enzymes, amylase, and catalase was investigated. One $\mathrm{mg} / \mathrm{ml}$ of enzymes including proteinase $\mathrm{K}$, pronase $\mathrm{E}$, trypsin, and chymotrypsin were prepared in $15 \mathrm{mM}$ sodium phosphate buffer $(\mathrm{pH}$ 7.2) and pepsin was prepared in glycine buffer $\mathrm{pH}$ 2. Before incubating for $2 \mathrm{~h}$ at $37^{\circ} \mathrm{C}$, proteases at a final concentration of $0.1 \mathrm{mg} / \mathrm{ml}$ were added. The crude cell free supernatant was treated with catalase at $0.1 \mathrm{mg} / \mathrm{ml}$ to remove 
potential inhibitory effects because of production of hydrogen peroxide.

\section{Targeting Bacteriocin Genes}

To detect genes encoding the known enterocins, genomic DNA of strain CM33 was used as template. PCR were performed in a Hybrid PCR Sprint thermocycler (Thermo Electron Corporation, Waltham, MA, USA) in $20 \mathrm{ml}$ reaction mixture (10 pmoles of each primer, $1 \mathrm{~mL}$ DNA template, and $1.25 \mathrm{U}$ Taq polymerase). The PCR conditions for enterocin-encoded genes are illustrated in Table 1. The PCR products were visualized by electrophoresis in $1.5 \%$ agarose gels.

\section{Bile Tolerance Test}

The method previously described by Pereira and Gibson (2002) was used to measure the viability of strain in bile salt. The isolate was grown in MRS medium supplemented with $0.5 \%(\mathrm{w} / \mathrm{v})$ oxgall then was incubated for $4 \mathrm{~h}$ at $37^{\circ} \mathrm{C}$. To determine of cell count, aliquots were plated onto MRS-agar medium at times $0,1,3$, and $4 \mathrm{~h}$. Control tube was without bile salt (Pereira and Gibson, 2002).

\section{Survivability in Simulated In Vitro Digestion}

Simulated in vitro digestion was carried out to evaluate the survival rate of strain CM33 in similar condition of the human gastrointestinal tract. To simulate the stomach digestion, samples ( $\mathrm{pH}$ 3.0) were treated with 5\% (w/v) pepsin (Sigma Chemical Co., Poole, UK) then were incubated for $120 \mathrm{~min}$ at $37^{\circ} \mathrm{C}$ with gentle agitation. The intestinal digestion was simulated by inoculating solutions of $0.1 \%(\mathrm{w} / \mathrm{v})$ pancreatin (Sigma Chemical Co., Poole, $\mathrm{UK})$ and $0.3 \%(\mathrm{w} / \mathrm{v})$ bile oxgall. The samples were incubated for $180 \mathrm{~min}$ at $37^{\circ} \mathrm{C}$ with gentle shaking. Samples were removed before and after gastric and intestinal digestion to measure cell count. The serially diluted aliquots were cultured on MRS agar medium and were incubated for $24 \mathrm{~h}$ under anaerobic conditions (Seiquer et al., 2001).

\section{Adhesion Ability to Caco-2 Cells}

Caco-2, the colon adenocarcinoma cell line, was used to evaluate the adhesion ability of E. faecium CM33 to human epithelial cells. RPMI medium supplemented with $10 \%(\mathrm{v} / \mathrm{v})$ fetal bovine serum and $1 \%(\mathrm{v} / \mathrm{v})$ penicillin/streptomycin mixture (Sigma Chemical Co., Poole, UK) was used to culture human colon cancer cells. Cells were seeded on 24-well tissue culture plates and incubated at $37^{\circ} \mathrm{C}$ in $5 \% \mathrm{CO}_{2}$ in a humidified atmosphere. Before the adhesion assay, fresh antibiotic-free RPMI was used to wash wells, which have a monolayer of Caco- 2 cells. Then, each well was inoculated with $1 \times 10^{7} \mathrm{cfu} / \mathrm{ml}$ of E. faecium in a total volume of $1 \mathrm{ml}$ and incubated at $37^{\circ} \mathrm{C}$ for $3 \mathrm{~h}$ in an atmosphere of $5 \%(\mathrm{v} / \mathrm{v}) \mathrm{CO}_{2}$. The wells were washed thrice with a pre-warmed phosphate buffer saline (Sigma Chemical Co., Poole, UK) to remove non-attached cells of E. faecium. To detach the cells, $1 \mathrm{ml}$ of $1 \%$ Triton X-100 (Sigma Chemical Co., Poole, UK) was added to each well with gently stirring for 5-10 min and then the viable human colon cancer cells, Caco-2, were counted. Finally, bacteria and Caco-2 cells were cultured onto MRS agar by the pure plate method and incubated at $37^{\circ} \mathrm{C}$ anaerobically. The total number of bacteria attached to viable Caco- 2 cells expressed as bacterial adhesion and carried out in triplicate.

\section{Inhibition of Pathogen Adhesion to Caco-2 cells}

Caco-2, human colon cells, were used to assess the effect of E. faecium treatment on the pathogen interaction with cells. E. faecium and pathogens (Escherichia coli, S. flexneri, $K$. pneumonia, and $S$. aureus) were cultured in MRS and LB, respectively. Overnight culture of E. faecium and pathogens were harvested and washed thrice with phosphate buffer saline. Bacteria were diluted in antibiotic-free RPMI and $0.5 \mathrm{ml} /$ well $\left(10^{8} \mathrm{CFU}\right.$ per well) of E. faecium suspension was inoculated to 24-well tissue culture plates. To evaluate the capability of E. faecium to restrain pathogenic bacteria adhesion to Caco2 cells, simultaneous addition of $10^{8} \mathrm{CFU}$ per well of tested

\begin{tabular}{|c|c|c|c|c|c|c|}
\hline A & EntA-R & CTCGTTAAGGTCCCTTCACG & & & & \\
\hline \multirow[t]{2}{*}{ B } & EntB-F & CAAAATGTAAAAGAATTAAGTACG & 201 & 56 & - & De Vuyst et al. (2003) \\
\hline & EntB-R & AGAGTATACATTTGCTAACCC & & & & \\
\hline \multirow[t]{2}{*}{$x$} & EntX-F & GTTTCTGTAAAAGAGATGAAAC & 500 & 50 & + & Edalatian et al. (2012) \\
\hline & EntX-R & САТАССААТТАСТААТТСТСС & & & & \\
\hline \multirow[t]{2}{*}{31} & Ent31-F & CCTACGTATTACGGAAATGGT & 130 & 58 & + & De Vuyst et al. (2003) \\
\hline & Ent31-R & GCCATGTTGTACCCAACCATT & & & & \\
\hline \multirow[t]{2}{*}{ Q } & EntQ-F & CAAGAAATITITCCCATGGC & 95 & 55 & + & Citti et al. (2002) \\
\hline & EntQ-R & ACGCTATGGTAAAAATTCTTC & & & & \\
\hline
\end{tabular}


pathogens was performed separately. Plates were incubated $1 \mathrm{~h}$ at $37^{\circ} \mathrm{C}$ and washed twice with sterile PBS then $1 \%(\mathrm{v} / \mathrm{v})$ Triton $\mathrm{X}-100$ (Sigma Chemical Co., Poole, UK) in deionized water for $5 \mathrm{~min}$ was used to lyse the cell-associated pathogens. To find out the number of viable cell-linked bacteria by colony forming counts, the suitable dilutions of the lysate were placed on LB agar. The inhibition analysis was calculated in three independent trials and each experiment was carried out in triplicate.

\section{Antimicrobial Activity}

To determine and identify inhibitory substances of metabolites produced by E. faecium CM33, well-diffusion method was performed (Hechard et al., 1990). Overnight cultures of the indicator strains were cultured in MRS agar at $37^{\circ} \mathrm{C}$ for $18 \mathrm{~h}$. $50 \mu \mathrm{l}$ of filtered crude supernatant of CM33 were dropped to each well $(5 \mathrm{~mm})$ into agar plates. The suspensions were inoculated to the wells and permitted to diffuse for $4 \mathrm{~h}$ at room temperature into MRS agar. The inhibition zone produced around the wells was determined after $24 \mathrm{~h}$ incubation at the optimum growth temperature of the indicator strains. The diameter of the produced inhibition zones around the wells was determined by digital caliper. These diameters were classified to four different groups including no inhibition $(-)$, weak $(+)$, good $(++)$, and strong $(+++)$. All trials were carried out in triplicate.

\section{PCR Detection of Virulence Factors in Enterococci}

Detection of genes encoding potential virulence factors in E. faecium CM33 was performed by PCR. Total bacterial DNA used as template in PCR reactions was isolated by the alkaline lysis method (Baele et al., 2001). Virulence genes evaluated in this study include: cytolysin (CylA, CylB, CylM; Semedo et al., 2003; Vankerckhoven et al., 2004), enterococcal surface protein (esp; Vankerckhoven et al., 2004), collagen-binding protein (ace; Omar et al., 2004), gelatinase (gelE), aggregation substance (agg; Eaton and Gasson, 2001; Ahmed et al., 2012), sex pheromone peptides (cpd; Abriouel et al., 2008), cell-wall anchored collagen adhesion (acm; Cariolato et al., 2008; Nallapareddy et al., 2008), and van A, van B, van C2 (Satake et al., 1997). E. faecium ATCC 51299 and ATCC 29212 were controls for this test. PCR was used to detect of genes encoding these factors using several primers (Table 2) which have been described by Eaton and Gasson (2001).

\section{Interpretation of Results}

Data were analyzed using SPSS 19.0 software (SPSS Inc., an IBM Company, Schaumburg, IL, USA). One-way ANOVA followed by multiple mean comparisons Duncan's test were used to assess statistical differences in multiple groups. Values are mean $\pm \mathrm{SE}$ and $p \leq 0.05$ is considered statistically significant.

\section{Results}

\section{Bacteria Isolation}

Screening of different dairy products like colostrum, yogurt, curd, cheese, and yogurt drink led to the isolation of E. faecium CM33 from ewe colostrum. After DNA extraction, the 16S rRNA fragments were amplified by PCR. According to 16S rRNA identification, 50 of the isolated bacteria were classified into three major groups of LAB, namely, $14 \%$ enterococci, $66 \%$ lactobacilli, and $20 \%$ lactococci. The isolates classified as LAB were also

TABLE 2 | Primers used for screening of virulence factors genes.

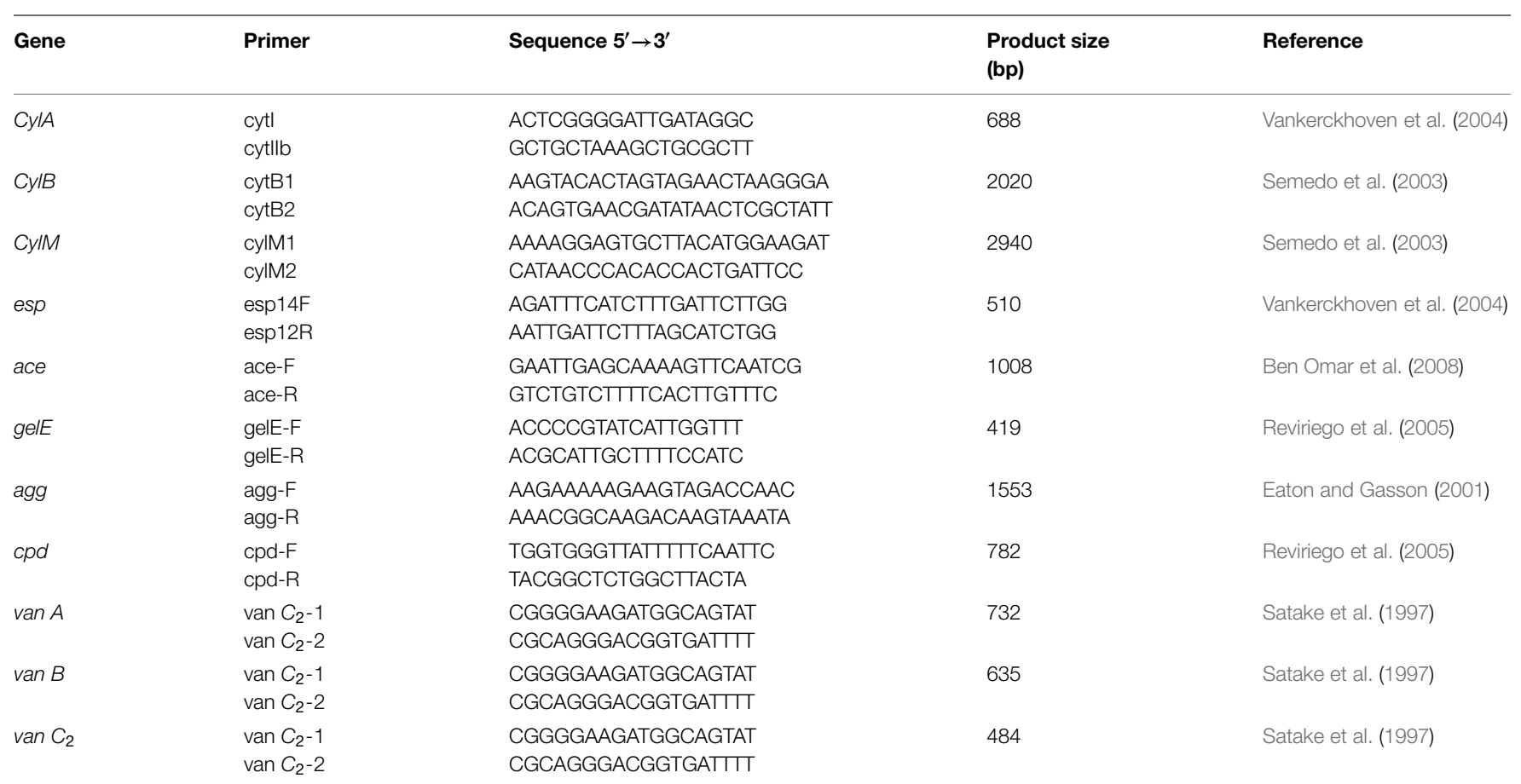


separated and identified by sequencing. After sequencing, the Enterococcus strains were categorized into E. lactis, E. hirae, E. avium, E. durans, E. faecalis, and E. faecium. The Lactobacillus strains representing $66 \%$ were classified into $L$. acidophilus and L. plantarum. The Lactococcus species were classified only into one species (Lactococcus lactis). Probiotic characterization of these isolates showed that E. faecium CM33 has the best properties such as tolerance to acid and bile, antimicrobial activity and antibiotic resistance thus it was selected for further analysis.

\section{Effects of pH, Heat, and Hydrolytic Enzymes on $E$. faecium Bacteriocin}

The stability and activity of E. faecium CM33 bacteriocins has been shown in Table 3. Bacteriocins were active over broad ranges of $\mathrm{pH}$ from 1.5 to 9 . It was also stable after autoclaving at $121^{\circ} \mathrm{C}$ for $15 \mathrm{~min}$. The treatment of cell free supernatant of E. faecium CM33 with amylase, catalase, and proteolytic enzymes showed that amylase and catalase enzymes do not influence on the bacteriocin activity, while proteolysis enzymes affect on the bacteriocin activity after $2 \mathrm{~h}$.

\section{PCR Analysis of Bacteriocin Genes}

PCR amplification using specific primers as shown in Table $\mathbf{1}$ was used to screen DNA of E. faecium CM33 for the existence of the known enterocin genes. This study focused on enterocin genes including $C y l$, A, P, 31, Q, X, L50A, and AS-48. E. faecium CM33 showed four bands: 95, 130, 248, and 500 bp corresponding to the specific amplification of enterocins Q, 31, Cyl, and X, respectively.

\section{Survivability in Bile Salt and Simulated Digestion}

Enterococcus faecium CM33 was incubated in $0.3 \%$ bile salts for $4 \mathrm{~h}$. It showed the survival rate of $>93 \%$ after this incubation period. One of the most desirable features needed for probiotics is the ability to survive in the GI tract. For further analysis, E. faecium CM33 was evaluated using simulated digestion test. This test revealed that this strain had $57.6 \%$ digestion survivability.

TABLE 3 | Effects of pH, heat, and enzymes (concentration $1 \mathrm{mg} / \mathrm{ml}$ ) on the antibacterial activity present in E. faecium CM33 culture metabolites.

\begin{tabular}{ll}
\hline Treatments & Antibacterial activity \\
\hline pH & + \\
$1.5-9$ & \\
Heat & + \\
$121^{\circ}$ C for 15 min & \\
Enzymes & - \\
Pepsin & - \\
Trypsin & - \\
Chymotrypsin & + \\
Proteinase K & + \\
Pronase E & - \\
Catalase & - \\
Amylase &
\end{tabular}

\section{Adhesion Assay to Caco-2 Cells}

The strain was tested further for its capability to colonize Caco2 cells. E. faecium CM33 showed the acceptable adhesion ability with an adhesion value of $32 \times 10^{4} \mathrm{cfu} / \mathrm{ml}$. E. faecium ATCC 29212, which used as a control to compare their adhesion ability, could not significantly adhere to Caco- 2 cells.

\section{Inhibition of Pathogens Adhesion}

In the presence of E. faecium CM33, the inhibition of pathogens adhesion was presented in Table 4. All the adherent pathogens were clearly reduced by co-culture with E. faecium. The reduction of E. coli, S. flexneri, K. pneumoniae, and S. aureus adhesion to Caco- 2 cells was more than $50 \%$ added with E. faecium $10^{8} \mathrm{CFU}$ per well.

\section{Antimicrobial Activity}

The strain CM33 isolated from colostrum displayed antimicrobial activity against all the tested indicator microorganisms (Table 5). The most sensitive indicators were L. monocytogenes, followed by Candida albicans. On the contrary, Clostridium difficile, Clostridium histolyticum, Salmonella typhimurium, and Streptococcus mutans were the less sensitive indicator microorganisms.

\section{Virulence Genes}

The presence of virulence genes in genomic DNA of E. faecium CM33 was screened by PCR. Currently several enterococci are being used as probiotics but they should be carefully assessed to ensure that they are not pathogenic. E. faecium CM33 was found to be negative for all tested virulent genes (Table 6). In the case of van $A$, van $B$ and van $C_{2}$ genes, it is essential to note that this result associate with the lack of resistance to vancomycin.

\section{Discussion}

The food industry is requested to present increasingly functional foods containing beneficial components because of the great

TABLE 4 | Inhibition of pathogens adhesion by co-culture with E. faecium CM33.

\begin{tabular}{|c|c|c|}
\hline \multirow[t]{2}{*}{ Pathogens } & \multicolumn{2}{|c|}{ Adhesive pathogen count ( $\left.10^{5} \mathrm{CFU} \mathrm{ml}{ }^{-1}\right)$} \\
\hline & Untreated & Co-cultured \\
\hline Clostridium difficile & $5.3 \pm 0.4$ & $3.7 \pm 0.3$ \\
\hline Clostridium histolyticum & $3.8 \pm 0.2$ & $2.8 \pm 0.4$ \\
\hline Staphylococcus aureus & $3.4 \pm 0.3$ & $1.1 \pm 0.2$ \\
\hline Staphylococcus saprophyticus & $4.6 \pm 0.2$ & $3.2 \pm 0.3$ \\
\hline Salmonella typhimurium & $7.1 \pm 0.3$ & $4.8 \pm 0.4$ \\
\hline Candida albicans & $6.4 \pm 0.4$ & $3.6 \pm 0.3$ \\
\hline Escherichia coli 0157 & $8.5 \pm 0.2$ & $3.8 \pm 0.2$ \\
\hline Bacillus cereus & $6.6 \pm 0.3$ & $4.0 \pm 0.4$ \\
\hline Listeria monocytogenes & $5.4 \pm 0.2$ & $2.5 \pm 0.2$ \\
\hline Klebsiella pneumoniae & $8.3 \pm 0.4$ & $4.1 \pm 0.3$ \\
\hline Shigella flexneri & $4.9 \pm 0.3$ & $1.3 \pm 0.4$ \\
\hline Pseudomonas aeroginosa & $5.2 \pm 0.2$ & $3.7 \pm 0.3$ \\
\hline Streptococcus mutans & $4.4 \pm 0.4$ & $2.7 \pm 0.2$ \\
\hline
\end{tabular}

Values are mean $\pm S E$. 
TABLE 5 | The antimicrobial activity of E. faecium CM33 against pathogens.

\begin{tabular}{lll}
\hline Pathogenic microorganisms & Source & Supernatant \\
\hline Clostridium difficile & ATCC 43255 & + \\
Clostridium histolyticum & ATCC 19401 & + \\
Staphylococcus aureus & ATCC 25923 & ++ \\
Staphylococcus saprophyticus & PTCC 1440 & ++ \\
Salmonella typhimurium & ATCC 14028 & + \\
Candida albicans & ATCC 10231 & +++ \\
Escherichia coli 0157 & PTCC 1276 & ++ \\
Bacillus cereus & ATCC 11778 & ++ \\
Listeria monocytogenes & PTCC 1163 & +++ \\
Klebsiella pneumoniae & ATCC 10031 & ++ \\
Shigella flexneri & PTCC 1234 & ++ \\
Pseudomonas aeroginosa & PTCC 1181 & ++ \\
Streptococcus mutans & ATCC 35668 & + \\
\hline
\end{tabular}

TABLE 6 | Detection of virulence-related genes in enterococcal strains used in this research.

\begin{tabular}{lll}
\hline Strain & Species & Virulent genes \\
\hline ATCC 29212 & E. faecium & gelE, cylA \\
ATCC 51299 & E. faecium & gelE, vanB, ccf, agg \\
CM33 & E. faecium & None \\
\hline
\end{tabular}

interest on health-oriented nutritional habits. Bacteria generally recognize as probiotic commonly belong to LAB. These microorganisms, as commensals in the human gastrointestinal tract, show a long history of use in foods and fermented products (Haghshenas et al., 2014a,b, 2015; Nami et al., 2014a,b,c). Enterococcus bacteria have various helpful functions in the dairy industry (Haghshenas et al., 2014c; Nami et al., 2014d). As starters, enterococci fulfill a considerable function in developing flavor progress and quality of cheeses. As probiotics, LAB are able to be used for healing of gut disorders in both humans and animals since these bacteria contribute to the intestinal health of the host by the development of gut microbial balance (Rehaiem et al., 2014). On the other hand, some requirements should be fulfilled to introduce a certain strain as a probiotic (Collins et al., 1998) and probiotic activities should be confirmed in well-made human studies. The aim of this paper was to evaluate safety and the potential beneficial properties of E. faecium CM33 isolated from ewe colostrum.

The most important characteristics required for microorganisms to be probiotics is their ability to survive while passing through the upper digestive tract to reach the large intestine, where their positive functions are predictable (Bezkorovainy, 2001; Tuomola et al., 2001; Nueno-Palop and Narbad, 2011). Probiotics can adhere to epithelial cells and should tolerate high acidic $\mathrm{pH}$ and high bile salt conditions in the gastric and intestinal fluid. Resistance to acid is of the popular properties used during the screening of potential probiotic strains. Another important mechanism in resisting intestinal pathogens and preventing diseases is the competition of probiotic bacteria with pathogens to adhere and colonize (Pascual et al., 2008). In this study, E. faecium CM33 isolated from ewe coloctrum dairy products was capable to survive both in bile salts and the gastric simulated digestion condition. This strain was further evaluated for their adhesion ability to Caco-2 cells. Data showed that E. faecium CM33 possessed an ability to resist the digestion conditions and was able to adhere to Caco-2 cells. These results show that E. faecium CM33 could be a suitable candidate to be as potential new probiotic.

The production of antimicrobial compounds like bacteriocins, organic acids, and hydrogen peroxide is of the well-designed properties applied to characterize probiotics (Rehaiem et al., 2014). Production of bacteriocins (enterocins) is the useful biotechnological trait of Enterococcus bacteria (Franz et al., 2011). The PCR results (Table 1; Figure 1) showed that E. faecium CM33 carried enterocins A, 31, Q, and X structural genes, while the other primers used in this test did not yield any visible band. Franz et al. (2007) classified enterocins A and 31 in the class IIa bacteriocins (pediocin-like bacteriocins). This group of bacteriocins is cationic and shows very effectual anti-Listeria activity and permeabilizes the cell membrane to kills target cells. Moreover, results showed that E. faecium CM33 has the greatest inhibitory function against L. monocytogenes. This fact could be described by the capability of Enterococcus bacteria to obtain and replace genetic information by conjugation (Brandão et al., 2010),
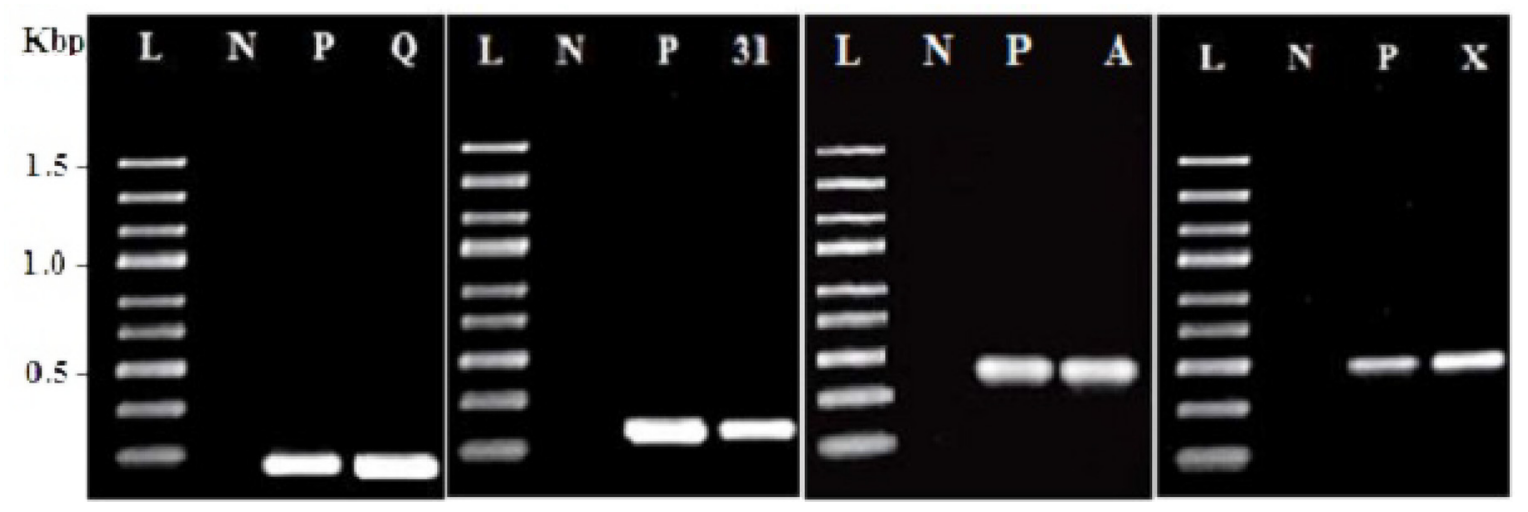

FIGURE 1 | Amplification results for screening enterocin genes in Enterococcus faecium CM33. L, molecular weight ladder (kbp); N, negative control; P, positive control by using purified DNA from a producer strain; $Q$, enterocin $Q ; 31$ : enterocin 31; $A$ : enterocin $A$ and $X$ : enterocin $X$. 
not only between strains of Enterococcus genus, but also with other genera (Strompfová et al., 2008).

The class IIb bacteriocins, two-peptide bacteriocins, also need two diverse peptides (enterocins Q and X) for activity. The production of multiple bacteriocins is not unusual and could be a general aspect of enterococci. Many Enterococcus bacteria are able to produce multiple bacteriocins, such as E. faecium WHE81 (Ennahar et al., 2001), E. faecium KV-B5 (Hu et al., 2010), E. faecium NKR-5-3A (Ishibashi et al., 2012), E. faecium JCM 5804T (Park et al., 2003), and E. faecium DAC2 (Sánchez et al., 2007). Nevertheless, the incidence of numerous enterocin genes in enterococci does not forever link with an advanced bacteriocin activity in their supernatants and not all enterocin genes should be expressed at the same time (Casaus et al., 1997).

Enterococcus faecium is the most normally occurring enterococcal species in dairy industry (Morandi et al., 2006) and fermented vegetable (Landeta et al., 2013). This species is also found in raw fruits (Abriouel et al., 2008) and probiotic preparations (Senok, 2009). However the nosocomial infections related to wound, bacteraemia, urinary-tract infections, and abdominal infections are caused by many enterococcal species (Thurlow et al., 2009). Enterococcus bacteria, as pathogens, have intrinsic and acquired resistance to many antibiotics that were considered as a major concern. The resistance against antibiotics and the production of virulence factors are two significant factors for the assessment of safety in enterococci. Probiotic strains may harbor antibiotic resistance genes that are able to be transferred to pathogenic bacteria. In particular, the most significant concern among antibiotic resistance is vancomycin resistance since it is the last antibiotics largely efficient against clinical infections by multidrug-resistant pathogens (Klein, 2003). Several studies elucidated the incidence of vancomycin-resistant enterococci in food of animal origin, mainly in E. faecium and E. faecalis species; although the isolation frequency seems to be lower than in clinical samples (Klein, 2003). In our case, CM33 strain was found to be susceptible to vancomycin, and this lack of resistance associated with the absence of van $A$, van $B$ and van $C_{2}$ genes. According to the EFSA, if the strain has one or more these genetic elements, this strain is unsafe and could not be applied as a feed additive (Ogier and Serror, 2008). Moreover, no resistance to other antibiotics such as gentamycin, erythromycin, tetracycline, and rifampicin was detected in this colostrum-isolated Enterococcus.

The potential pathogenicity of CM33 strain was evaluated by assessing the existence of genes encoding for other virulence factors, as determined by studies in various enterococcal species (Omar et al., 2004). Genes encoding for cell-wall anchored collagen adhesion $(\mathrm{acm})$, aggregation substance $(\mathrm{agg})$, cytolysin $(c y l A)$, and gelatinase ( $g e l E)$ were not found in our isolated strain. Besides, the amplification for a sex pheromones gene (ccf), which could be involved in initiating conjugation processes (Clewell, 2011) was negative.

One of important properties of strain to be as a potential probiotic is anti-pathogen activity. In vitro test under neutralized $\mathrm{pH}$ was performed using 13 pathogenic microorganisms and supernatants (metabolites) obtained from the exponential E. faecium CM33 culture. The well diffusion technique was performed to evaluate the inhibitory effect of the CM33 strain against 13 pathogenic microorganisms. The E. faecium supernatant demonstrated the strong inhibition function against indicator pathogens (Table 5). This strain was found to have the strongest inhibition activity against $L$. monocytogenes and Candida albicans. It was recommended that E. faecium CM33 produced bacteriocins (enterocin A and 31) to inhibit these pathogens.

According to previous studies, the multiple enterocinsproducing isolate is likely more capable and could display a wider range of inhibition in inhibiting the growth of undesirable bacteria than a simple bacteriocin producer (Ishibashi et al., 2012). E. faecium DAC2 (producer both Ent A and Ent P) produces a higher antagonistic activity than those of the controls E. faecium T136 and E. faecium P13 (producer of enterocin A and enterocin P, respectively; Sánchez et al., 2007). The production of bacteriocins by LAB helps LAB to be colonized in their habitats and to compete with other bacteria (Garriga et al., 1993). Many factors including decreased $\mathrm{pH}$ levels, competition for substrates, and the production of substances such as bacteriocins are caused the antimicrobial activity of LAB (Parente and Ricciardi, 1999).

The competitive inhibition of enteropathogen attachment to epithelial cells by LAB is another important factor. So, the competitive inhibition of adherence of pathogenic bacteria to Caco-2 cells by adhering E. faecium CM33 cells was evaluated. This strain was able to strongly inhibit the adhesion of many tested pathogens (Table 4). However, the mechanisms by which LAB inhibit pathogen adhesion to human cell lines in vitro are not fully understood. Steric hindrance rather than blockage of specific receptors may be involved (Bernet et al., 1993). Additional trials are required to discover the exact mechanism of inhibition observed in this study.

\section{Conclusion}

An identified strain of E. faecium from colostrum can present interesting probiotic characteristics. It can stay alive during passing the digestive system and has ability to be colonized on the intestinal epithelial cells. In addition, this strain showed a significant enteropathogen growth inhibiting activity and interference with pathogens adhesion to human colon Caco2 cells. These features could enable this strain to establish itself in the intestinal tract and to compete with other bacterial species. However, the safety and implications for public health of individual enterococcal strains must be carefully evaluated to fully exploit their industrial potential.

\section{Ethical Issues}

No ethical issues to be promulgated.

\section{Acknowledgments}

The financial support of the University Putra Malaysia and the Faculty of Pharmacy, Tabriz University of Medical Sciences, Tabriz, Iran are gratefully acknowledged. 


\section{References}

Abriouel, H., Omar, N. B., Molinos, A. C., López, R. L., Grande, M. J., Martínez-Viedma, P., et al. (2008). Comparative analysis of genetic diversity and incidence of virulence factors and antibiotic resistance among enterococcal populations from raw fruit and vegetable foods, water and soil, and clinical samples. Int. J. Food Microbiol. 123, 38-49. doi: 10.1016/j.ijfoodmicro.2007.11.067

Ahmed, W., Sidhu, J., and Toze, S. (2012). Speciation and frequency of virulence genes of Enterococcus spp. isolated from rainwater tank samples in Southeast Queensland, Australia. Environ. Sci. Technol. 46, 6843-6850. doi: $10.1021 /$ es300595g

Baele, M., Storms, V., Haesebrouck, F., Devriese, L. A., Gillis, M., Verschraegen, G., et al. (2001). Application and evaluation of the interlaboratory reproducibility of tRNA intergenic length polymorphism analysis (tDNA-PCR) for identification of Streptococcus species. J. Clin. Microbiol. 39, 1436-1442. doi: 10.1128/JCM.39.4.1436-1442.2001

Ben Omar, N., Abriouel, H., Keleke, S., Sánchez Valenzuela, A., MartínezCañamero, M., Lucas López, R., et al. (2008). Bacteriocin-producing Lactobacillus strains isolated from poto poto, a Congolese fermented maize product, and genetic fingerprinting of their plantaricin operons. Int. J. Food microbiol. 127, 18-25. doi: 10.1016/j.ijfoodmicro.2008 05.037

Bernet, M.-F., Brassart, D., Neeser, J., and Servin, A. (1993). Adhesion of human bifidobacterial strains to cultured human intestinal epithelial cells and inhibition of enteropathogen-cell interactions. Appl. Environ. Microbiol. 59, 4121-4128.

Bezkorovainy, A. (2001). Probiotics: determinants of survival and growth in the gut. Am. J. Clin. Nutr. 73, 399s-405s.

Brandão, A., Almeida, T., Muñoz-Atienza, E., Torres, C., Igrejas, G., Hernández, P., et al. (2010). Antimicrobial activity and occurrence of bacteriocin structural genes in Enterococcus spp. of human and animal origin isolated in Portugal. Arch. Microbiol. 192, 927-936. doi: 10.1007/s00203-0100619-z

Cariolato, D., Andrighetto, C., and Lombardi, A. (2008). Occurrence of virulence factors and antibiotic resistances in Enterococcus faecalis and Enterococcus faecium collected from dairy and human samples in North Italy. Food Control 19, 886-892. doi: 10.1016/j.foodcont.2007.08.019

Carlos, A., Semedo-Lemsaddek, T., Barreto-Crespo, M., and Tenreiro, R (2010). Transcriptional analysis of virulence-related genes in enterococci from distinct origins. J. Appl. Microbiol. 108, 1563-1575. doi: 10.1111/j.13652672.2009.04551.x

Casaus, P., Nilsen, T., Cintas, L. M., Nes, I. F., Hernández, P. E., and Holo, H. (1997). Enterocin B, a new bacteriocin from Enterococcus faecium T136 which can act synergistically with enterocin A. Microbiology 143, 2287-2294. doi: 10.1099/00221287-143-7-2287

Cintas, L. M., Casaus, P., Herranz, C., Hâvarstein, L. S., Holo, H., Hernández, P. E., et al. (2000). Biochemical and genetic evidence that Enterococcus faecium L50 produces enterocins L50A and L50B, the sec-dependent enterocin P, and a novel bacteriocin secreted without an $\mathrm{N}$-terminal extension termed enterocin Q. J. Bacteriol. 182, 6806-6814. doi: 10.1128/JB.182.23.6806-6814.2000

Citti, L., Rovero, P., Colombo, M. G., Mariani, L., Poliseno, L., and Rainaldi, G. (2002). Efficacy of an amphipathic oligopeptide to shuttle and release a cis-acting DNA decoy into human cells. Biotechniques 32 $172-177$.

Clewell, D. B. (2011). Tales of conjugation and sex pheromones: a plasmid and enterococcal odyssey. Mob. Genet. Elements 1, 38-54. doi: 10.4161/mge.1.1.15409

Collins, J., Thornton, G., and Sullivan, G. (1998). Selection of probiotic strains for human applications. Int. Dairy J. 8, 487-490. doi: 10.1016/S09586946(98)00073-9

De Vuyst, L., Foulquié Moreno, M. R., and Revets, H. (2003). Screening for enterocins and detection of hemolysin and vancomycin resistance in enterococci of different origins. Int. J. Food Microbiol. 84, 299-318. doi: 10.1016/S0168-1605(02)00425-7

Dunne, C., O'mahony, L., Murphy, L., Thornton, G., Morrissey, D., O'halloran, S., et al. (2001). In vitro selection criteria for probiotic bacteria of human origin: correlation with in vivo findings. Am. J. Clin. Nutr. 73, $386 s-392$ s.
Du Toit, M., Franz, C. M., Dicks, L. M., and Holzapfel, W. H. (2000). Preliminary characterization of bacteriocins produced by Enterococcus faecium and Enterococcus faecalis isolated from pig faeces. J. Appl. Microbiol. 88, 482-494. doi: 10.1046/j.1365-2672.2000. 00986.x

Eaton, T. J., and Gasson, M. J. (2001). Molecular screening of Enterococcus virulence determinants and potential for genetic exchange between food and medical isolates. Appl. Environ. Microbiol. 67, 1628-1635. doi: 10.1128/AEM.67.4.1628-1635.2001

Edalatian, M. R., Habibi Najafi, M. B., Mortazavi, S. A., Alegría, Á., Delgado, S., Bassami, M. R., et al. (2012). Production of bacteriocins by Enterococcus spp. isolated from traditional, Iranian, raw milk cheeses, and detection of their encoding genes. Eur. Food Res. Technol. 234, 789-796. doi: 10.1007/s00217-0121697-8

Eijsink, V. G., Axelsson, L., Diep, D. B., Håvarstein, L. S., Holo, H., and Nes, I. F. (2002). Production of class II bacteriocins by lactic acid bacteria; an example of biological warfare and communication. Antonie Van Leeuwenhoek 81, 639-654. doi: 10.1023/A:1020582211262

Ennahar, S., Asou, Y., Zendo, T., Sonomoto, K., and Ishizaki, A. (2001). Biochemical and genetic evidence for production of enterocins $\mathrm{A}$ and $\mathrm{B}$ by Enterococcus faecium WHE 81. Int. J. Food Microbiol. 70, 291-301. doi: 10.1016/S0168-1605(01)00565-7

Franz, C. M., Huch, M., Abriouel, H., Holzapfel, W., and Gálvez, A. (2011). Enterococci as probiotics and their implications in food safety. Int. J. Food Microbiol. 151, 125-140. doi: 10.1016/j.ijfoodmicro.2011. 08.014

Franz, C. M., Van Belkum, M. J., Holzapfel, W. H., Abriouel, H., and Gálvez, A. (2007). Diversity of enterococcal bacteriocins and their grouping in a new classification scheme. FEMS Microbiol. Rev. 31, 293-310. doi: 10.1111/j.15746976.2007.00064.x

Garriga, M., Hugas, M., Aymerich, T., and Monfort, J. (1993). Bacteriocinogenic activity of Lactobacilli from fermented sausages. J. Appl. Bacteriol. 75, 142-148. doi: 10.1111/j.1365-2672.1993.tb02759.x

Gilmore, M. S., Segarra, R. A., Booth, M. C., Bogie, C. P., Hall, L. R., and Clewell, D. B. (1994). Genetic structure of the Enterococcus faecalis plasmid pAD1encoded cytolytic toxin system and its relationship to lantibiotic determinants. J. Bacteriol. 176, 7335-7344.

Haghshenas, B., Abdullah, N., Nami, Y., Radiah, D., Rosli, R., and Khosroushahi, A. Y. (2014a). Different effects of two newly-isolated probiotic Lactobacillus plantarum $15 \mathrm{HN}$ and Lactococcus lactis subsp. Lactis 44Lac strains from traditional dairy products on cancer cell lines. Anaerobe 30, 51-59. doi: 10.1016/j.anaerobe.2014.08.009

Haghshenas, B., Nami, Y., Abdullah, N., Radiah, D., Rosli, R., Barzegari, A., et al (2014b). Potentially probiotic acetic acid bacteria isolation and identification from traditional dairies microbiota. Int. J. Food Sci. Technol. 50, 1056-1064. doi: $10.1111 /$ ijfs. 12718

Haghshenas, B., Nami, Y., Abdullah, N., Radiah, D., Rosli, R., and Khosroushahi, A. Y. (2014c). Anti-proliferative effects of Enterococcus strains isolated from fermented dairy products on different cancer cell lines. J. Funct. Foods 11, 363-374. doi: 10.1016/j.jff.2014.10.002

Haghshenas, B., Nami, Y., Abdullah, N., Radiah, D., Rosli, R., and Khosroushahi, A. Y. (2015). Anticancer impacts of potentially probiotic acetic acid bacteria isolated from traditional dairy microbiota. LWT Food Sci. Technol. 60, 690-697. doi: 10.1016/j.lwt.2014.09.058

Hechard, Y., Dherbomez, M., Cenatiempo, Y., and Letellier, F. (1990). Antagonism of lactic acid bacteria from goats' milk against pathogenic strains assessed by the 'sandwich method.' Lett. Appl. Microbiol. 11, 185-188. doi: 10.1111/j.1472765X.1990.tb00156.x

Hickey, R. M., Twomey, D. P., Ross, R. P., and Hill, C. (2003). Production of enterolysin A by a raw milk enterococcal isolate exhibiting multiple virulence factors. Microbiology 149, 655-664. doi: 10.1099/mic.0. 25949-0

Hu, C.-B., Malaphan, W., Zendo, T., Nakayama, J., and Sonomoto, K. (2010). Enterocin X, a novel two-peptide bacteriocin from Enterococcus faecium KUB5, has an antibacterial spectrum entirely different from those of its component peptides. Appl. Environ. Microbiol. 76, 4542-4545. doi: 10.1128/AEM. 02264-09

Ishibashi, N., Himeno, K., Fujita, K., Masuda, Y., Perez, R. H., Zendo, T. et al. (2012). Purification and characterization of multiple bacteriocins 
and an inducing peptide produced by Enterococcus faecium NKR-5-3 from Thai fermented fish. Biosci. Biotechnol. Biochem. 76, 947-953. doi: 10.1271/bbb.110972

Khan, H., Flint, S., and Yu, P.-L. (2010). Enterocins in food preservation. Int. J. Food Microbiol. 141, 1-10. doi: 10.1016/j.ijfoodmicro.2010. 03.005

Kirjavainen, P. V., Ouwehand, A. C., Isolauri, E., and Salminen, S. J. (1998). The ability of probiotic bacteria to bind to human intestinal mucus. FEMS Microbiol. Lett. 167, 185-189. doi: 10.1111/j.1574-6968.1998. tb13226.x

Klein, G. (2003). Taxonomy, ecology and antibiotic resistance of enterococci from food and the gastro-intestinal tract. Int. J. Food Microbiol. 88, 123-131. doi: 10.1016/S0168-1605(03)00175-2

Kullen, M., Sanozky-Dawes, R., Crowell, D., and Klaenhammer, T. (2000). Use of the DNA sequence of variable regions of the 16S rRNA gene for rapid and accurate identification of bacteria in the Lactobacillus acidophilus complex. J. Appl. Microbiol. 89, 511-516. doi: 10.1046/j.1365-2672.2000. 01146.x

Landeta, G., Curiel, J. A., Carrascosa, A. V., Muñoz, R., and De Las Rivas, B. (2013). Technological and safety properties of lactic acid bacteria isolated from Spanish dry-cured sausages. Meat Sci. 95, 272-280. doi: 10.1016/j.meatsci.2013. 05.019

Line, J., Svetoch, E., Eruslanov, B., Perelygin, V., Mitsevich, E., Mitsevich, I., et al. (2008). Isolation and purification of enterocin E-760 with broad antimicrobial activity against gram-positive and gram-negative bacteria. Antimicrob. Agents Chemother. 52, 1094-1100. doi: 10.1128/AAC.01569-06

Morandi, S., Brasca, M., Andrighetto, C., Lombardi, A., and Lodi, R. (2006). Technological and molecular characterisation of enterococci isolated from north-west Italian dairy products. Int. Dairy J. 16, 867-875. doi: 10.1016/j.idairyj.2005.09.005

Moreno, M. F., Sarantinopoulos, P., Tsakalidou, E., and De Vuyst, L. (2006). The role and application of enterococci in food and health. Int. J. Food Microbiol. 106, 1-24. doi: 10.1016/j.ijfoodmicro.2005.06.026

Nallapareddy, S. R., Singh, K. V., Okhuysen, P. C., and Murray, B. E. (2008). A functional collagen adhesin gene, acm, in clinical isolates of Enterococcus faecium correlates with the recent success of this emerging nosocomial pathogen. Infect. Immun. 76, 4110-4119. doi: 10.1128/IAI. 00375-08

Nami, Y., Abdullah, N., Haghshenas, B., Radiah, D., Rosli, R., and Khosroushahi, A. Y. (2014a). Assessment of probiotic potential and anticancer activity of newly isolated vaginal bacterium Lactobacillus plantarum 5BL. Microbiol. Immunol. 58, 492-502. doi: 10.1111/1348-0421.12175

Nami, Y., Abdullah, N., Haghshenas, B., Radiah, D., Rosli, R., and Khosroushahi, A. Y. (2014b). Probiotic assessment of Enterococcus durans 6HL and Lactococcus lactis 2HL isolated from vaginal microflora. J. Med. Microbiol. 63, 1044-1051. doi: 10.1099/jmm.0.074161-0

Nami, Y., Abdullah, N., Haghshenas, B., Radiah, D., Rosli, R., and Khosroushahi, A. Y. (2014c). Probiotic potential and biotherapeutic effects of newly isolated vaginal Lactobacillus acidophilus 36YL strain on cancer cells. Anaerobe 28, 29-36. doi: 10.1016/j.anaerobe.2014.04.012

Nami, Y., Abdullah, N., Haghshenas, B., Radiah, D., Rosli, R., and Yari Khosroushahi, A. (2014d). A newly isolated probiotic Enterococcus faecalis strain from vagina microbiota enhances apoptosis of human cancer cells. J. Appl. Microbiol. 117, 498-508. doi: 10.1111/ jam. 12531

Nes, I. F., Diep, D. B., and Holo, H. (2007). Bacteriocin diversity in Streptococcus and Enterococcus. J. Bacteriol. 189, 1189-1198. doi: 10.1128/ JB.01254-06

Nueno-Palop, C., and Narbad, A. (2011). Probiotic assessment of Enterococcus faecalis CP58 isolated from human gut. Int. J. Food Microbiol. 145, 390-394. doi: 10.1016/j.ijfoodmicro.2010.12.029

Ogier, J.-C., and Serror, P. (2008). Safety assessment of dairy microorganisms: the Enterococcus genus. Int. J. Food Microbiol. 126, 291-301. doi: 10.1016/j.ijfoodmicro.2007.08.017

Omar, N. B., Castro, A., Lucas, R., Abriouel, H., Yousif, N. M., Franz, C. M., et al. (2004). Functional and safety aspects of enterococci isolated from different Spanish foods. Syst. Appl. Microbiol. 27, 118-130. doi: 10.1078/0723-202000248
Parente, E., and Ricciardi, A. (1999). Production, recovery and purification of bacteriocins from lactic acid bacteria. Appl. Biochem. Biotechnol. 52, 628-638. doi: $10.1007 / \mathrm{s} 002530051570$

Park, S., Itoh, K., and Fujisawa, T. (2003). Characteristics and identification of enterocins produced by Enterococcus faecium JCM 5804T. J. Appl. Microbiol. 95, 294-300. doi: 10.1046/j.1365-2672.2003. 01975.x

Pascual, L. M., Daniele, M. B., Ruiz, F., Giordano, W., Pájaro, C., and Barberis, L. (2008). Lactobacillus rhamnosus L60, a potential probiotic isolated from the human vagina. J. Gen. Appl. Microbiol. 54, 141-148. doi: 10.2323/ jgam.54.141

Pereira, D. I., and Gibson, G. R. (2002). Cholesterol assimilation by lactic acid bacteria and bifidobacteria isolated from the human gut. Appl. Environ. Microbiol. 68, 4689-4693. doi: 10.1128/AEM.68.9.46894693.2002

Rehaiem, A., Belgacem, Z. B., Edalatian, M. R., Martínez, B., Rodríguez, A., Manai, M., et al. (2014). Assessment of potential probiotic properties and multiple bacteriocin encoding-genes of the technological performing strain Enterococcus faecium MMRA. Food Control 37, 343-350. doi: 10.1016/j.foodcont.2013.09.044

Reviriego, C., Eaton, T., Martín, R., Jiménez, E., Fernández, L., Gasson, M. J., et al. (2005). Screening of virulence determinants in Enterococcus faecium strains isolated from breast milk. J. Hum. Loct. 21, 131-137. doi: 10.1177/0890334405275394

Sánchez, J., Basanta, A., Gómez-Sala, B., Herranz, C., Cintas, L., and Hernández, P. (2007). Antimicrobial and safety aspects, and biotechnological potential of bacteriocinogenic enterococci isolated from mallard ducks (Anas platyrhynchos). Int. J. Food Microbiol. 117, 295-305. doi: 10.1016/j.ijfoodmicro.2007.04.012

Satake, S., Clark, N., Rimland, D., Nolte, F. S., and Tenover, F. C. (1997). Detection of vancomycin-resistant enterococci in fecal samples by PCR. J. Clin. Microbiol. 35, 2325-2330.

Seiquer, I., Aspe, T., Vaquero, P., and Navarro, P. (2001). Effects of heat treatment of casein in the presence of reducing sugars on calcium bioavailability: in vitro and in vivo assays. J. Agric. Food Chem. 49, 1049-1055. doi: 10.1021/ jf001008v

Semedo, T., Santos, M. A., Martins, P., Lopes, M. F. S., Marques, J. J. F., Tenreiro, R., et al. (2003). Comparative study using type strains and clinical and food isolates to examine hemolytic activity and occurrence of the cyl operon in enterococci. J. Clin. Microbiol. 41, 2569-2576. doi: 10.1128/JCM.41.6.25692576.2003

Senok, A. C. (2009). Probiotics in the arabian gulf region. Food Nutr. Res. 53. doi: 10.3402/fnr.v53i0.1842

Sparo, M., Castro, M., Andino, P., Lavigne, M., Ceriani, C., Gutiérrez, G., et al. (2006). Partial characterization of enterocin MR99 from a corn silage isolate of Enterococcus faecalis. J. Appl. Microbiol. 100, 123-134. doi: 10.1111/j.13652672.2005.02752.x

Strompfová, V., Lauková, A., Simonová, M., and Marciňáková, M. (2008). Occurrence of the structural enterocin A, P, B, L50B genes in enterococci of different origin. Vet. Microbiol. 132, 293-301. doi: 10.1016/j.vetmic.2008. 05.001

Tarasova, E., Yermolenko, E., Donets, V., Sundukova, Z., Bochkareva, A., Borshev, I., et al. (2010). The influence of probiotic Enterococcus faecium strain L5 on the microbiota and cytokines expression in rats with dysbiosis induced by antibiotics. Benef. Microbes 1, 265-270. doi: 10.3920/ BM2010.0008

Thirabunyanon, M., and Hongwittayakorn, P. (2013). Potential probiotic lactic acid bacteria of human origin induce antiproliferation of colon cancer cells via synergic actions in adhesion to cancer cells and short-chain fatty acid bioproduction. Appl. Biochem. Biotechnol. 169, 511-525. doi: 10.1007/s12010012-9995-y

Thurlow, L. R., Thomas, V. C., Fleming, S. D., and Hancock, L. E. (2009). Enterococcus faecalis capsular polysaccharide serotypes C and D and their contributions to host innate immune evasion. Infect. Immun. 77, 5551-5557. doi: 10.1128/IAI.00576-09

Tuomola, E., Crittenden, R., Playne, M., Isolauri, E., and Salminen, S. (2001). Quality assurance criteria for probiotic bacteria. Am. J. Clin. Nutr. 73, 393s398s. 
Tuomola, E. M., and Salminen, S. J. (1998). Adhesion of some probiotic and dairy Lactobacillus strains to Caco-2 cell cultures. Int. J. Food Microbiol. 41, 45-51. doi: 10.1016/S0168-1605(98)00033-6

Vankerckhoven, V., Van Autgaerden, T., Vael, C., Lammens, C., Chapelle, S., Rossi, R., et al. (2004). Development of a multiplex PCR for the detection of asal, gelE, cylA, esp, and hyl genes in enterococci and survey for virulence determinants among European hospital isolates of Enterococcus faecium. J. Clin. Microbiol. 42, 4473-4479. doi: 10.1128/JCM.42.10.4473-4479.2004

Wang, Z., Chai, W., Burwinkel, M., Twardziok, S., Wrede, P., Palissa, C., et al. (2013). Inhibitory influence of Enterococcus faecium on the propagation of swine influenza A virus in vitro. PLOS ONE 8:e53043. doi: 10.1371/journal.pone.0053043
Conflict of Interest Statement: The authors declare that the research was conducted in the absence of any commercial or financial relationships that could be construed as a potential conflict of interest.

Copyright (c) 2015 Nami, Haghshenas, Haghshenas and Yari Khosroushahi. This is an open-access article distributed under the terms of the Creative Commons Attribution License (CC BY). The use, distribution or reproduction in other forums is permitted, provided the original author(s) or licensor are credited and that the original publication in this journal is cited, in accordance with accepted academic practice. No use, distribution or reproduction is permitted which does not comply with these terms. 